\title{
Predictors for changing to a non-Nursing profession
}

Os preditores à mudança de profissão de Enfermagem

Los predictores de los cambios a la profesión de Enfermería

Ana Filipa da Silva Poeira*iD; Ricardo Nuno Ferreira Paes Mamede**iD;

Maria Manuela Ferreira Pereira da Silva Martins*** (DD

\section{Abstract}

Background: Nurses' predisposition to change their profession lies within the scope of nurse turnover. Understanding the reasons why nurses want to switch to another organization or even leave the profession is important because this movement has a negative impact on the workgroup and the organization.

Objective: To determine the propensity to leave the nursing profession.

Methodology: Descriptive, correlational, cross-sectional, and quantitative study. The non-probability sample of 463 nurses was recruited through the snowball method.

Results: The nurses who were under the age of 40 and worked in the public sector were more willing to leave the nursing profession. The greater the satisfaction with the profession and the greater the professional autonomy and recognition, the lower the nurses' probability to change to another profession.

Conclusions: Health organizations should concentrate on retaining their nurses by adopting human resource strategies that value them and organizational models focused on motivation and satisfaction.

Keywords: human resources; personnel turnover; job satisfaction; nursing

\section{Resumo}

Enquadramento: A predisposiçáo dos enfermeiros para mudar de profissão enquadra-se na rotatividade em enfermagem. Compreender os motivos que levam os enfermeiros a querer mudar de organização ou até mesmo abandonar a profissão é fundamental, visto que essa movimentaçáo traz consigo implicaçóes negativas no grupo de trabalho e na organização.

Objetivo: Determinar a propensão para o abandono da profissão de enfermagem.

Metodologia: Estudo descritivo, correlacional, transversal e quantitativo. A amostra, do tipo não-probabilístico, é constituída por 463 enfermeiros acedidos mediante a técnica de snowball.

Resultados: São os enfermeiros com idades inferiores a 40 anos e a desempenhar funções no setor público que apresentam maior vontade de abandonar a profissáo de enfermagem. Verifica-se também que quanto maior for a satisfação com a profissão e maior a autonomia e reconhecimento profissional, menor será a probabilidade de os enfermeiros mudarem de profissão.

Conclusáo: É fundamental que as organizações de saúde se preocupem com a retençáo dos seus enfermeiros, adotando estratégias de recursos humanos que valorizem os mesmos e com modelos organizacionais voltados para a motivação e satisfação.

Palavras-chave: recursos humanos; reorganização de recursos humanos; satisfaçáo no emprego; enfermagem

*Ph.D., Guest Adjunct Professor, School of Health of the Polytechnic Institute of Setúbal. Integrated Researcher, NURSE'IN Nursing Research Unit for South and Islands, 2914-503, Setúbal, Portugal [ana.poeira@ess.ips.pt]. D https://orcid.org/0000-0002-9924-7526.Contribution to the article: literature search, data collection, statistical treatment and evaluation, data analysis and discussion, article writing. Address for correspondence: ESS/IPS Estefanilha, 2914-503, Setúbal, Portugal.

**Ph.D., Assistant Professor and Deputy Director of the Department of Political Economy, ISCTE - University Institute of Lisbon, Department of Economics. Integrated Researcher, DINÂMIACET-IUL - Center for Research on Socioeconomic Change and Territory (ECSH) [Governance, Economics, and Citizenship], 1649-026, Lisboa, Portugal [ricardomamede@iscte-iul.pt]. (D) https://orcid.org/0000-0001-9738-7480. Contribution to the article: data analysis and discussion, article writing.

***:Ph.D., Coordinating Professor, Nursing School of Porto. Researcher, Health and Technology Research Center, Research Group NursID: Nursing Innovation and Development, 4200-072, Porto, Portugal [mmartins@esenf.pt]. (1) https://orcid.org/0000-0003-1527-9940. Contribution to the article: data analysis and discussion, article writing

\section{Resumen}

Marco contextual: La predisposición de los enfermeros a cambiar de profesión forma parte de la rotatividad en enfermería. Comprender las razones que llevan a los enfermeros a querer cambiar su organización o incluso a abandonar la profesión es esencial, ya que este movimiento conlleva implicaciones negativas en el grupo de trabajo y en la organización.

Objetivo: Determinar la propensión a abandonar la profesión de enfermería.

Metodología: Estudio descriptivo, correlacional, transversal y cuantitativo. La muestra no probabilística consistió en 463 enfermeros a los que se accedió a través de la técnica de la bola de nieve.

Resultados: Los enfermeros menores de 40 años que trabajan en el sector público son los que están más dispuestos a dejar la profesión de enfermería. También se encontró que cuanto mayor es la satisfacción con la profesión y mayor es la autonomía y el reconocimiento profesional, menos probable es que los enfermeros cambien de profesión.

Conclusión: Es esencial que las organizaciones de salud se preocupen por mantener a sus enfermeros, para lo cual deben adoptar estrategias de recursos humanos que los valoren, así como implementar modelos organizativos enfocados en la motivación y la satisfacción.

Palabras clave: recursos humanos; reorganización del personal; satisfacción en el trabajo; enfermería 


\section{Introduction}

In 1860, Florence Nightingale founded what is known by modern nursing, starting its path with the development of an identity of its own as a socio-professional group (Neumaier, Corrêa, Soares, \& Könzgen, 2015). The nursing profession focuses on providing care and meeting patients' basic human needs in an intrepid and scientific manner.

Given the complexity of nursing care, which implies a holistic vision of the human being, there are several theories and models to guide knowledge in clinical practice, education, and management. However, in recent years, Portugal and the several governmental sectors have been faced with a paralyzed economy and increasingly larger budget deficits (Mamede, 2015). These changes have had an impact on health organizations, thus creating new challenges for nurse managers.

According to data from the Organization for Economic Cooperation and Development (OECD), in 2014, the Portuguese health spending accounted for $10.2 \%$ of the gross domestic product, when compared to the average of $8.7 \%$ in the European Union (EU; OECD, 2015). Although health spending has decreased over the past few years, it still remains well above the EU average.

Due to the public deficit, the nurses working in the National Health Service (Serviço Nacional de Saúde, SNS) were confronted with cost-cutting measures, such as the freezing of career progression since August 2005; wage restraint; increased workload; and less shift allowances, vacation days, and public holidays. In the public health sector, the nursing career is still frozen. These measures have caused dissatisfaction among this professional class. In addition to dissatisfaction, the workload and the work volume have also increased. High workloads lead to dissatisfaction, lack of motivation, and burnout among nurses, putting into question the quality of nursing care (Ordem dos Enfermeiros [OE], 2014). In 2013, Portugal had one of the lowest numbers of nurses per capita (6.1 nurses per 100,000 inhabitants) out of the 28 countries of the EU, being only ahead of Slovakia, Poland, Spain, Latvia, and Greece (OECD, 2015). According to data from the Union of Portuguese Nurses (Sindicato dos Enfermeiros Portugueses, SEP), by the end of 2016, more than 67,000 days off were owed to Portuguese nurses working in the public sector (SEP, 2016).
The willingness to leave the nursing profession, which is a precursor of turnover, often finds its origins here.

Portugal has an aging population. According to OECD data (2017), 20.3\% of the Portuguese population is aged over 65 years, in contrast to $18.9 \%$ of the population in the EU, and the birth rate is $1.3 \%$ in Portugal (significantly less when compared to $1.6 \%$ in the EU). The older the population, the greater the need for health care and, inevitably, human resources.

Understanding the propensity to leave the nursing profession allows directing human resource management practices to intervene in effective decision-making, given that leaving the profession contributes to high rates of external turnover (Hayes et al., 2012). The issue of external turnover is essential because if employees leave the organization, that will have an impact on productivity, knowledge, intellectual capital, and organizational health (Bilhim, 2005). In turn, these losses are associated with high costs (Duffield et al., 2011). In the nursing area, high turnover rates compromise the quality of care and, consequently, the delivery of safe care to meet patients' needs (Al-Hussain \& Aleem, 2014; Duffield et al., 2011; Poeira, 2017). This justifies the relevance of the topic. However, many of the existing studies on turnover do not distinguish it from the intention to leave the profession, by which the main purpose of this study is to determine the propensity to leave the nursing profession.

\section{Background}

Nurse turnover, which is a phenomenon that includes the change of profession, continues to be a complex issue with serious consequences for health organizations, being partly the reason why the development of studies on this topic is of paramount importance.

Nurse turnover is divided into two types: 1) internal turnover, which involves nurses taking new positions in services within the same organization (International Council of Nurses, 2002); and 2) external turnover, the process by which the nurses leave the organization or even the profession (Hayes et al., 2012).

Several theoretical models have been developed to explain this phenomenon, particularly in the nursing area. According to the different authors who have studied this issue, several variables can 
affect external turnover, namely: organizational factors; workload, stress, and burnout; leadership style; empowerment; individual characteristics; career progression, pay, and benefits (Hayes et al., 2012). The main purpose of the studies on the impact of these factors on nurse turnover is to find solutions for reducing the turnover rates.

The high nurse turnover rates have an impact on key areas of the management of the human resources of an organization or service: 1) they negatively influence productivity (North \& Hughes, 2006); 2) they lead to possible economic losses (Duffield et al., 2011);3) they contribute to the negative impact on the quality of care (Al-Hussain \& Aleem, 2014); 4) they increase the likelihood of error occurrence (Castilho, 2014); 5) they contribute to a negative impact on team cohesion ( $\mathrm{Lu}$, While, \& Barriball, 2005); 6) they contribute to a state of stress until the new member is integrated (Lu et al., 2005); and 7) they contribute to reducing consensus and increasing conflict (Santos et al., 2007).

Leaving the profession often reveals a lack of professional achievement which, in turn, causes dissatisfaction and even burnout. In a study conducted in Sweden on a sample of 1417 new nursing graduates, the authors found that the levels of burnout were associated with the intention to leave the profession because the longitudinal analysis revealed that these levels increase in the early years of professional activity and, consequently, increase the prevalence of intention to leave the nursing profession (Rudman, Gustavsson, \& Hultell, 2014). The development of human resource management measures capable of counteracting the intention to change to another profession will promote professional achievement and satisfaction, as well as contribute to the retention of professionals in the organization.

\section{Research question}

What are the predictors of the propensity to leave the nursing profession?

\section{Methodology}

Based on the literature review, a survey by questionnaire was conducted. It included: a) sociodemographic and professional variables; $b$ ) variables of external turnover; c) variables of propensity to turnover in the future; and d) factors adding value to the workplace environment. The questionnaire was revised and assessed by experts in the area and pretested in individuals belonging to the target group. It was individually completed and confidential. A total of 108 answers were obtained, which were used to test the suitability of the questionnaire to the target group, namely the analysis of its internal consistency by calculating Cronbach's alpha coefficient. The rating scale on the characteristics of the work environment obtained a total Cronbach's alpha value of 0.857 , revealing a good internal consistency. The suitability of the factor analysis of this scale was determined using the Kaiser-Meyer-Olkin test $(K M O=0.743)$ and Bartlett's test of sphericity. A value of 922.129, $p=0.000$ was obtained, which make it consistent with the underlying theoretical conceptions.

The study was approved by the Abel Salazar Institute of Biomedical Sciences - University of Porto, in 2012. It was also here that the data collection tool and the informed consent form were discussed.

A descriptive, correlational, cross-sectional, and quantitative study was conducted. Data were collected through a questionnaire between April and May 2014. An online questionnaire was applied using Google Forms. It was emailed to all the nurses' contacts on the list of the principal investigator with a request to forward it to each one's contact list. The non-probability convenience sample is composed of 463 nurses who were recruited using the snowball technique. The inclusion criteria were: being a nurse and accepting to voluntarily participate in the study. The exclusion criterion was to be an active member of the $\mathrm{OE}$, but working in a profession other than nursing at the moment of questionnaire completion.

Data were analyzed using IBM SPSS Statistics, version 20.0. In addition to the descriptive statistics for sample characterization, univariate analysis techniques were used to check for differences in the propensity to change profession based on some socioprofessional variables (type of organization; employment relationship; age; and gender) and multivariate techniques (logistic regression model) were used to identify the predictors of the propensity to leave the nursing profession which, in this study, represents the dependent variable (DV). This variable was rated on a 5-point scale. Par- 
ticipants were asked to score from 1 (never) to 5 (always) their answer to the question: "Have you ever thought about leaving the nursing profession?".

Prior to the regression analysis, the DV was converted into a dichotomous variable "High propensity to leave the profession"; "Low propensity to leave the profession".

Eight workplace environment factors valued by nurses were selected as independent variables (IV), resulting from a principal component analysis. In addition to the workplace environment factors valued by nurses, other factors may also influence the propensity to leave the profession. The literature shows that some sociodemographic variables, as well as variables of organizational and professional satisfaction, can have a predictive effect on behavior. For this reason, the following variables were also used in the model: "gender", "age", "academic qualifications", "seniority", "workplace”, "professional category", "double employment", "satisfaction with nursing", and "satisfaction with the organization".

The indicators of multicollinearity were analyzed through the linear regression analysis and the value of tolerance and the variance inflation factor (VIF) were estimated. As shown in Table 1 , multicollinearity is not a problem in this study because the values of tolerance and VIF for all model variables scored higher than 0.1 and less than 10 , respectively, which means a low increase in variance due to the existence of a relationship between the model variables.

Table 1

Measure of tolerance and VIF values for the independent variables: workplace environment factors valued by nurses; sociodemographic and professional variables; satisfaction variables

\begin{tabular}{lll}
\hline \multirow{2}{*}{ Independent variables } & \multicolumn{2}{c}{ Collinearity statistics } \\
\cline { 2 - 3 } & Tolerance & VIF \\
\hline Workplace environment factors values by nurses & & \\
Work organization and offered conditions & 0.328 & 3.047 \\
Workload and work volume & 0.580 & 1.724 \\
Pay and progression & 0.729 & 1.371 \\
Professional growth & 0.485 & 2.060 \\
Human relationships & 0.718 & 1.392 \\
Professional autonomy and recognition & 0.535 & 1.868 \\
Geographical proximity to family/friends & 0.660 & 1.516 \\
Contractual stability & 0.769 & 1.300 \\
Sociodemographic and professional variables & & \\
Gender & 0.926 & 1.079 \\
Age & 0.391 & 2.560 \\
Academic qualifications & 0.915 & 1.093 \\
Seniority & 0.422 & 2.370 \\
Workplace & 0.818 & 1.222 \\
Professional category & 0.486 & 2.056 \\
Double employment & 0.883 & 1.133 \\
Satisfaction variables & & \\
Satisfaction with nursing & 0.638 & 1.568 \\
Satisfaction with the organization & 0.610 & 1.639 \\
\hline
\end{tabular}

Note. VIF = variance inflation factor. 
Given the different types of independent variables, the sequential logistic regression model was used. The variables were placed in three blocks and the Enter method was used: the first block, with the workplace environment factors valued by nurses; the second block, with the sociodemographic and professional variables; and, finally, the third block, with the satisfaction variables.

\section{Results}

\section{Brief sample characterization}

The sample was composed of 463 nurses: 336 (72.6\%) women and $123(26.6 \%)$ men, and four did not respond $(0.8 \%)$. The participants were aged between 24 and 57 years, with a mean age of 36.6 years $( \pm 8.763)$. The majority of participants were aged between 30 and 39 years $(44.9 \%, n$
$=208)$. The majority of respondents worked in the district of Lisbon $(39.1 \%, n=181)$, followed by the districts of Coimbra $(14.7 \%, n=68)$ and Porto $(9.9 \%, n=46)$. It should be noted that the percentage of participants from the other districts ranged from $0.4 \%$ to $6.3 \% ; 4.3 \%(n=20)$ of the nurses were emigrants.

Table 2 shows the results of the descriptive analysis of the variable "Propensity to change to a non-Nursing profession". The mean score obtained was $2.5( \pm 1.026)$ and the majority of participants ( $n=202 ; 43.7 \%)$ answered that they "sometimes" wanted to change their profession. A high number of participants also answered "never" (22.3\%,n= $103)$ and "rarely" (20.6\%, $n=95)$, but it should be noted that 264 participants $(57.2 \%)$, corresponding to more than half of the sample, had already felt the desire to leave the nursing profession at some point in their lives.

Table 2

Summary statistics of the variable "Propensity to change profession"

\begin{tabular}{lcc}
\hline Have you ever thought about leaving the nursing profession? & $\boldsymbol{N}$ & $\boldsymbol{\%}$ \\
\hline Never & 103 & 22.3 \\
Rarely & 95 & 20.6 \\
Sometimes & 202 & 43.7 \\
Often & 52 & 11.3 \\
Always & 10 & 2.2 \\
Total & 462 & 100 \\
\hline
\end{tabular}

Note. Mean $=2.50 ; S D=1.026$. A participant did not answer.

Analysis of the "Propensity to leave the nursing profession" based on the variables: "gender"; "age"; "type of organization"; and "employment relationship"

To check for any differences between groups in the "propensity to change profession", depending on the variables of gender, age, type of organization, and employment relationship, the Mann-Whit- ney (gender) and Kruskal-Wallis (age, type of organization, and employment relationship) tests were performed after verification of the non-normal distribution of the DV (Kolmogorov-Smirnov test, $p<0.05$ ).

Table 3 shows no statistically significant differences between male and female nurses in relation to the propensity to change profession $(U=$ 19273.0; $p=0.242$ ).

Table 3

Results of the Mann-Whitney test for the variables 'propensity to change profession' and 'gender'

\begin{tabular}{lcccc}
\hline Variable & \multicolumn{2}{c}{ Gender } & Test \\
\hline \multirow{2}{*}{ Propensity to change profession } & $\begin{array}{c}\mathrm{M} \\
(n=123)\end{array}$ & $\begin{array}{c}\mathrm{F} \\
(n=336)\end{array}$ & $\mathrm{U}$ & $p$ \\
\cline { 2 - 4 } & Mean rank & Mean rank & & \\
\cline { 2 - 4 } & 241.31 & 225.86 & & 0.242 \\
\hline
\end{tabular}

Note. $M=$ male; $F=$ female $U=$ Mann-Whitney; $p=$ significance. 
With regard to the age variable, which was recoded in age classes, the nonparametric Kruskal-Wallis test was used. Statistically significant differences were found between the groups $(\mathrm{H}$
$=19.201 ; p=0.000)$, being the nurses aged between 30 and 39 years those who were more prone to change profession, followed by the nurses aged less than 29 years (Table 4).

Table 4

Results of the Kruskal-Wallis test for the variables 'propensity to change profession' and 'age'

\begin{tabular}{|c|c|c|c|c|c|c|}
\hline Variable & \multicolumn{4}{|c|}{ Age } & \multicolumn{2}{|c|}{ Test } \\
\hline \multirow{3}{*}{$\begin{array}{l}\text { Propensity to change } \\
\text { profession }\end{array}$} & $\begin{array}{c}\text { Less than } 29 \\
\text { years } \\
(n=123)\end{array}$ & $\begin{array}{c}30-39 \text { years } \\
\quad(n=207)\end{array}$ & $\begin{array}{c}40-49 \text { years } \\
(n=97)\end{array}$ & $\begin{array}{c}\text { More than } 50 \\
\text { years } \\
(n=33)\end{array}$ & $H$ & $P$ \\
\hline & \multicolumn{4}{|c|}{ Mean ranks } & & 0000 \\
\hline & 231.67 & 253.29 & 199.22 & 175.12 & & 0.000 \\
\hline
\end{tabular}

Note. $H=$ Kruskal-Wallis H-test; $p=$ significance.

For the variable "employment relationship" (Table 5), no statistically significant differences were found between the groups in the propensity to change profession $(\mathrm{H}=4.246 ; p=0.374)$.

Table 5

Results of the Kruskal-Wallis test for the variables 'propensity to change profession' and 'employment relationship'

\begin{tabular}{|c|c|c|c|c|c|c|c|}
\hline Variable & \multicolumn{5}{|c|}{ Professional relationship } & \multicolumn{2}{|c|}{ Test } \\
\hline \multirow[t]{3}{*}{$\begin{array}{l}\text { Propensity to } \\
\text { change profession }\end{array}$} & $\begin{array}{c}\text { Fixed-term } \\
\text { employment } \\
\text { contract } \\
(n=26)\end{array}$ & $\begin{array}{c}\text { Employment } \\
\text { contract of } \\
\text { indefinite } \\
\text { duration } \\
(n=240)\end{array}$ & $\begin{array}{c}\text { Employment } \\
\text { contract in } \\
\text { civil service } \\
(n=166)\end{array}$ & $\begin{array}{c}\text { Service } \\
\text { delivery } \\
(n=9)\end{array}$ & $\begin{array}{l}\text { Other } \\
(n=14)\end{array}$ & $H$ & $P$ \\
\hline & \multicolumn{5}{|c|}{ Mean ranks } & & \\
\hline & 202.23 & 227.00 & 228.57 & 227.28 & 286.61 & 8 & $0.3 / 4$ \\
\hline
\end{tabular}

With regard to the variable "type of organization", Table 6 shows statistically significant differences between the distributions of the different groups $(\mathrm{H}=15.459 ; p=0.014)$. The nurses working in public hospitals were more prone to change profession, followed closely by the nurses working in healthcare centers.

Table 6

Results of the Kruskal-Wallis test for the variables 'propensity to change profession' and' type of organization'

\begin{tabular}{|c|c|c|c|c|c|c|c|}
\hline Variable & \multicolumn{5}{|c|}{ Type of organization } & \multicolumn{2}{|c|}{ Test } \\
\hline \multirow{3}{*}{$\begin{array}{l}\text { Propensity to change } \\
\text { profession }\end{array}$} & $\begin{array}{c}\text { Public } \\
\text { hospital } \\
(n=301)\end{array}$ & $\begin{array}{c}\text { Private } \\
\text { organization } \\
(n=52)\end{array}$ & $\begin{array}{l}\text { Healthcare } \\
\text { center } \\
(n=48)\end{array}$ & $\begin{array}{l}\text { School } \\
(n=31)\end{array}$ & $\begin{array}{l}\text { Other } \\
(n=20)\end{array}$ & $\mathrm{H}$ & $\mathrm{P}$ \\
\hline & \multicolumn{5}{|c|}{ Mean ranks } & & \\
\hline & 237.79 & 211.81 & 233.68 & 156.81 & 185.60 & 15.459 & 0.004 \\
\hline
\end{tabular}

Note. $H=$ Kruskal-Wallis $\mathrm{H}$ test; $p=$ significance. 
Logistic regression - predictors of the propensity to change profession

Initially, the model fit was assessed using the Omnibus and Hosmer-Lemeshow tests. Table 7 shows a good fit of the model to the data (Omnibus test: Chi-square $_{(17)}=88.892 \mathrm{p}=$ $0.000)$, representing the data in an adequate manner (Hosmer-Lemeshow test: Chi-square ${ }_{(8)}$ $=6.530 ; \mathrm{p}=0.588)$.

The summary model values, namely Nagelkerke $\mathrm{R}^{2}$ (0.361), allow concluding that this model, with its predictor variables, has a significant explanatory power over the low propensity of a nurse to change profession, explaining $36.1 \%$ of the variance.

Table 7

Model summary and model fitting data

\begin{tabular}{lccc}
\hline \multirow{2}{*}{ Omnibus test of model coefficients } & Chi-square & df & P \\
\cline { 2 - 4 } Model summary & 88.892 & 17 & 0.000 \\
\hline \multirow{2}{*}{ Hosmer-Lemeshow test } & -2 Log-likelihood & $\begin{array}{c}\text { Cox and } \\
\text { Snell R }\end{array}$ & Negelkerk R $^{2}$ \\
\cline { 2 - 4 } & 228.451 & 0,192 & 0.361 \\
\hline
\end{tabular}

Table 8 shows the effects of the predictor variables, revealing that most of them have no significant effect on the propensity to change profession (Wald statistic: $p>0.05$ ).

However, Table 8 also shows that the variable "professional autonomy and recognition" and the variable "satisfaction with nursing" have a significant effect on the low propensity to change profession $(p<0.05)$. Based on the odds ratio (OR), these variables can be ranked according to their effect on the propensity to change profession, with the most important variable for the propensity to change profession being the "satisfaction with nursing" (Table 8), followed by "professional autonomy and recognition” (Table 8$)$.

Table 8

Statistics of the regression model of propensity to change profession

\begin{tabular}{lcccccc}
\hline Predictor variables & B & DP & Wald & Df & sig. & Exp(B) \\
\hline Work organization and offered conditions & -1.061 & 0.636 & 2.783 & 1 & 0.095 & 0.346 \\
Workload and work volume & -0.524 & 0.349 & 2.259 & 1 & 0.133 & 0.592 \\
Pay and progression & -0.223 & 0.384 & 0.337 & 1 & 0.562 & 0.800 \\
Professional growth & -0.134 & 0.495 & 0.073 & 1 & 0.787 & 0.875 \\
Human relationships & 0.323 & 0.349 & 0.858 & 1 & 0.354 & 1.382 \\
Professional autonomy and recognition & 1.151 & 0.499 & 5.326 & 1 & $\mathbf{0 . 0 2 1}$ & $\mathbf{3 . 1 6 1}$ \\
Geographical proximity to family/friends & 0.335 & 0.338 & 0.978 & 1 & 0.323 & 1.397 \\
Contractual stability & 0.239 & 0.401 & 0.355 & 1 & 0.551 & 1.270 \\
Gender & -0.411 & 0.414 & 0.982 & 1 & 0.322 & 0.663 \\
Age & 0.570 & 0.350 & 2.645 & 1 & 0.104 & 1.768 \\
Academic qualifications & 0.031 & 0.134 & 0.051 & 1 & 0.821 & 1.031 \\
Seniority & -0.080 & 0.338 & 0.056 & 1 & 0.812 & 0.923 \\
Workplace & -0.341 & 0.183 & 3.456 & 1 & 0.063 & 0.711 \\
Professional category & 0.130 & 0.244 & 0.284 & 1 & 0.594 & 1.139 \\
\hline
\end{tabular}




\begin{tabular}{lcccccc}
\hline Double employment & -0.093 & 0.413 & 0.051 & 1 & 0.821 & 0.911 \\
Satisfaction with nursing & 1.934 & 0.325 & 35.450 & 1 & $\mathbf{0 . 0 0 0}$ & $\mathbf{6 . 9 1 4}$ \\
Satisfaction with the organization & 0.007 & 0.248 & 0.001 & 1 & 0.977 & 1.007 \\
Constant & -3.077 & 2.500 & 1.516 & 1 & 0.218 & 0.046 \\
\hline
\end{tabular}

Note. $\mathrm{B}$ = regression coefficient; $\mathrm{SD}=$ standard deviation; $\mathrm{Df}=$ degrees of freedom; sig. = significance of the Wald statistic; $\operatorname{Exp}(\mathrm{B})=$ exponent of the regression coefficient.

When analyzing the $O R$, the model shows that the higher the professional satisfaction $(O R=6.914)$ and the professional autonomy and recognition $(O R=3.161)$, the lower is the propensity to change profession. Professionally satisfied nurses are ten times more likely to change their profession and nurses with more professional autonomy and recognition are three times more likely to not change their profession.

\section{Discussion}

Nurses aged less than 40 years and working in the public sector (public hospital and healthcare center) are more willing to change profession. Considering nurses' contractual specificities and conditions in the public sector, it may be due to the lack of career progression and to compensation issues. The recent OECD report on the health profile of Portugal mentions that the higher salaries in the private sector are encouraging both doctors and nurses to leave the public sector or even to emigrate to other countries (OECD, 2017).

In her study on external turnover in Nursing, Poeira (2017) concluded that the "Opportunity to increase income" was one of the most commonly mentioned factors by nurses as contributing to their decision to change organization, revealing that nurses seek salaries that are compatible with the high complexity and responsibility of their work.

According to the OECD report (2017), the future challenge of the SNS is to maintain the motivation of its workforce and reverse the external turnover rates.

This study revealed that the variables "professional satisfaction" and "professional autonomy and recognition" are essential for this professional group, influencing decisions that will affect their daily practice and that which characterizes the profession: caring. It shows that these two variables, when taken into account by the health organizations, directly influence the nurses' likelihood to leave the profession. To sum up, the greater the professional satisfaction, autonomy, and recognition, the lower the nurses' probability to leave the nursing profession and, consequently, the lower the external turnover rates.

Similarly to the results obtained in this study, the study of Simon, Müller, and Hasselhorn (2010) concluded that both the intention to leave the organization and the intention to leave the nursing profession are associated with age, burnout, professional commitment, and job satisfaction.

The intention to leave the profession is a complex issue influenced by multiple factors, and it is necessary to develop strategies that promote a suitable workload and a safe working environment, reducing the levels of burnout and enabling personal growth and professional development (Rudman et al., 2014).

Another key issue is the need for professional autonomy and recognition.

In a study aimed to identify factors associated with workplace justice and nurses' intention to leave the profession, Chin et al. (2019) concluded that autonomy at work and a fair performance appraisal system are the most important factors influencing nurses' intention to leave the profession.

The results revealed the need to adopt human resource management strategies to maintain high levels of motivation and satisfaction among nurses.

A limitation of this study was that it did not include organizational commitment as a predictor variable, thus future studies should also consider it.

\section{Conclusion}

External nurse turnover in the SNS is increasing. The literature identifies several factors that have contributed to this phenomenon, namely pay and benefits, career progression, enhancement of professional skills, reduced workload and work volume, among others, and that should be considered in nurse retention strategies. The challenge will be the identification of the key factors influencing turnover, including emigration and leaving the profession, because only then will it be possible to implement measures aimed at motivating and 
increasing the professional satisfaction of nurses and, consequently, improving the quality of nursing care.

It is essential to retain nurses in the SNS while minimizing costs and ensuring the quality of nursing care delivery.

To find answers to these issues, the managers of human resources for health should, above all, value nurses and use organizational models focused on motivation and satisfaction.

\section{References}

Al-Hussain, K., \& Aleem, M. (2014). Impact of job satisfaction on employee turnover: An empirical study of Autonomous Medical Institutions of Pakistan. Journal of International Studies, 7(1), 122-132. doi:10.14254/2071-8330.2014/7-1/11.

Bilhim, J. A. (2005). Teoria organizacional: Estruturas e pessoas. Lisboa, Portugal: ISCSP.

Castilho, A. (2014). Eventos adversos nos cuidados de enfermagem ao doente internado: Contributos para a politica de segurança (Doctoral thesis). Universidade do Porto, Instituto de Ciências Biomédicas Abel Salazar, Portugal. Retrieved from http://hdl.handle. net/10216/78357

Chin, W., Guo, Y.-L., Hung, Y.-J., Hsieh, Y.-T., Wang, L.-J., \& Shiao, J. S.-C. (2019). Workplace justice and intention to leave the nursing profession. Nursing Ethics, 26(1), 307-319. doi:10.1177/0969733016687160

Duffield, C., Diers, D., O’Brien-Pallas, L., Aisbett, C., Roche, M., King, M., \& Aisbett, K. (2011). Nursing staffing, nursing workload, the work environment and patient outcomes. Applied Nursing Research, 24(4), 244-255. doi:10.1016/j.apnr.2009.12.004.

Hayes, L., O’Brien-Pallas, L., Duffield, C., Shamian, J., Buchan, J. Hughes, F., Laschinger, H., \& North, N. (2012). Nurse turnover: A literature review: An update. International Journal of Nursing Studies, 49(7), 889-905. doi: 10.1016/j.ijnurstu.2011.10.001

International Council of Nurses. (ICN). (2002). Career moves and migration: Critical questions. Geneva, Switzerland: Author.

Lu, H., While, A. E. \& Barriball, K. L. (2005). Job satisfaction among nurses: A literature review. International Journal of Nursing Studies, 42(2), 211-227. doi: 10.1016/j.ijnurstu.2004.09.003

Mamede, R. P. (2015). O que fazer com este país. Barcarena,
Portugal: Marcador.

Neumaier, C. A., Corrêa, A. C., Soares, M. C., \& Könzgen, S. M. (2015). O cuidado de enfermagem e sua evolução histórica: Uma revisão integrativa. Cultura de los Cuidados, 19(43). doi:10.14198/cuid.2015.43.09

North, N., \& Hughes, F. (2006). Methodological challenges to researching nursing turnover in New Zealand: A progress report of a national study. Asia Pacific Journal of Health Management, 1(1), 45-51. Retrieved from https://search.informit.com.au/documentSummary; $\mathrm{dn}=628733330779463$; res=IELHEA

Organization for Economic Cooperation and Development. (2015). "Nurses", in health at a glance 2015: OECD indicators. Paris, France: Author. doi:10.1787/ health_glance-2015-26-en

Organization for Economic Cooperation and Development. (2017). State of health in the EU, Portugal: Country health profile 2017. Retrieved from http://www.oecd-ilibrary.org/social-issues-migration-health/portugal-country-health-profile-2017_ 9789264283527-en

Ordem dos Enfermeiros. (2014). Dados estatísticos a 31 12-2013. Lisboa, Portugal: Autor.

Poeira, A. (2017). Rotatividade externa dos enfermeiros em Portugal (Doctoral thesis). Universidade do Porto, Instituto Ciências Biomédicas Abel Salazar, Portugal. Retrieved from http://hdl.handle.net/10216/88637

Rudman, A., Gustavsson, P., \& Hultell, D. (2014). A prospective study of nurses' intentions to leave the profession during their first five years of practice in Sweden. International Journal of Nursing Studies, 51(4), 612-624. doi:10.1016/j.ijnurstu.2013.09.012

Santos, O., Biscaia, S. A., Antunes, A. R., Craveiro, I., Júnior, A., Caldeira, R., \& Charondière, P. (2007). Os Centros de Saúde em Portugal: A satisfação dos utentes e dos profissionais ( $1^{\mathrm{a}} \mathrm{ed}$.). Lisboa, Portugal: Ministério da Saúde. Retrieved from http://www.ago. com.pt/data/files/pdf/Partilhar\%20saude/Portugal/ CdSaude_Portugal_2007.pdf

Simon, M., Müller, B. H., \& Hasselhorn, H. M. (2010). Leaving the organization or the profession: A multilevel analysis of nurses' intentions. Journal of Advanced Nursing, 66(3), 616-626. doi:10.1111/j. 1365-2648.2009.05204.x

Sindicato dos Enfermeiros Portugueses. (2016). Hospitais estão a dever mais de 67 mil dias de folga aos enfermeiros. Retrieved from https://www.sep.org.pt/ artigo/imprensa/hospitais-estao-a-dever-mais-de-67mil-dias-de-folga-aos-enfermeiros/ 
